\title{
Halogen species record Antarctic sea ice extent over glacial-interglacial periods
}

\author{
A. Spolaor ${ }^{1,2}$, P. Vallelonga ${ }^{3}$, J. M. C. Plane ${ }^{4}$, N. Kehrwald ${ }^{5}$, J. Gabrieli ${ }^{2}$, C. Varin ${ }^{5}$, C. Turetta ${ }^{2}$, G. Cozzi ${ }^{2}$, \\ R. Kumar $^{6}$, C. Boutron ${ }^{7}$, and C. Barbante ${ }^{2,5}$ \\ ${ }^{1}$ Department of Earth Science, University of Siena, Via Laterina 8, 53100 Siena, Italy \\ ${ }^{2}$ Institute for the Dynamics of Environmental Processes - CNR, University of Venice, Dorsoduro 2137, 30123 Venice, Italy \\ ${ }^{3}$ Centre for Ice and Climate, Niels Bohr Institute, Juliane Maries Vej 30, 2100 Copenhagen, Denmark \\ ${ }^{4}$ School of Chemistry, University of Leeds, Leeds, LS2 9JT, UK \\ ${ }^{5}$ Department of Environmental Sciences, Informatics and Statistics, University Ca' Foscari of Venice, Dorsoduro 2137,30123 \\ Venice, Italy \\ ${ }^{6}$ Department of Chemistry, Multanimal Modi (Postgraduate) College, Modinagar-201204 (UP), India \\ ${ }^{7}$ Laboratoire de Glaciologie et Géophysique de l'Environnement (UMR UJF/CNRS 5183), 54, rue Molière, Domaine \\ Universitaire, B.P. 96, 38402 Saint Martin d' Hères, France
}

Correspondence to: A. Spolaor (andrea.spolaor@unive.it)

Received: 12 December 2012 - Published in Atmos. Chem. Phys. Discuss.: 12 February 2013

Revised: 10 June 2013 - Accepted: 12 June 2013 - Published: 12 July 2013

\begin{abstract}
Sea ice is an integral part of the earth's climate system because it affects planetary albedo, sea-surface salinity, and the atmosphere-ocean exchange of reactive gases and aerosols. Bromine and iodine chemistry is active at polar sea ice margins with the occurrence of bromine explosions and the biological production of organoiodine from sea ice algae. Satellite measurements demonstrate that concentrations of bromine oxide ( $\mathrm{BrO}$ ) and iodine oxide (IO) decrease over sea ice toward the Antarctic interior. Here we present speciation measurements of bromine and iodine in the TALDICE (TALos Dome Ice CorE) ice core $\left(159^{\circ} 11^{\prime} \mathrm{E}, 72^{\circ} 49^{\prime} \mathrm{S} ; 2315\right.$ $\mathrm{m}$ a.s.l.) spanning the last $215 \mathrm{ky}$. The Talos Dome ice core is located $250 \mathrm{~km}$ inland and is sensitive to marine air masses intruding onto the Antarctic Plateau. Talos Dome bromide $\left(\mathrm{Br}^{-}\right)$is positively correlated with temperature and negatively correlated with sodium (Na). Based on the $\mathrm{Br}^{-} / \mathrm{Na}$ seawater ratio, bromide is depleted in the ice during glacial periods and enriched during interglacial periods. Total iodine, consisting of iodide $\left(\mathrm{I}^{-}\right)$and iodate $\left(\mathrm{IO}_{3}^{-}\right)$, peaks during glacials with lower values during interglacial periods. Although $\mathrm{IO}_{3}^{-}$is considered the most stable iodine species in the atmosphere it was only observed in the TALDICE record during glacial maxima. Sea ice dynamics are arguably the primary driver of halogen fluxes over glacial-interglacial
\end{abstract}

timescales, by altering the distance between the sea ice edge and the Antarctic plateau and by altering the surface area of sea ice available to algal colonization. Based on our results we propose the use of both halogens for examining Antarctic variability of past sea ice extent.

\section{Introduction}

The atmospheric chemistry of iodine (I) and bromine (Br) are receiving increasing attention on account of their importance for photochemical atmospheric processes. Recent developments in atmospheric iodine chemistry include gas phase reaction kinetics, breakthroughs in the understanding of iodine reaction cycles in ambient air and ensuing CCN (cloud condensation nuclei) production (Saiz-Lopez et al., 2012). Bromine is important for its ozone depletion capabilities (Simpson et al., 2007b) and associated applications in atmospheric research (Wofsy et al., 1975).

Though the oceans are considered the main reservoirs and emission sources of I and $\mathrm{Br}$ (Greenwood, 2005), satellite observations (Schönhardt et al., 2008, 2012; Kaleschke et al., 2004; Frieß et al., 2004; Nghiem et al., 2012; Saiz-Lopez et 
al., 2007a) have linked I and Br activity to sea ice in the polar regions.

The main source of atmospheric iodine is oceanic biogenic production (Wong, 1991; Saiz-Lopez et al., 2012), in which iodine is injected into the atmosphere as organic iodine compound (R-I) that is subsequently oxidized into inorganic species in the presence of ozone and light (Vogt et al., 1999). However, recent laboratory data suggest additional abiotic production lend a non-negligible contribution of $\mathrm{I}_{2}$ to atmospheric iodine (Saiz-Lopez et al., 2012; Carpenter et al., 2013). Recently it has been postulated that algae growing under sea ice also heavily contribute to the total iodine concentration in the atmosphere (Saiz-Lopez et al., 2007b; Atkinson et al., 2012) especially in the Antarctic region.

Iodine is a highly reactive element and undergoes rapid photochemical reactions in the polar atmosphere. In Antarctica, thin seasonal sea ice acts as a substrate for algal growth and permits the percolation of iodine compounds up to the atmosphere. Satellite images clearly demonstrate enhanced concentrations of IO above circum-Antarctic sea ice during springtime (Schönhardt et al., 2008). The production of IO is attributable to the photochemical degradation of compounds such as $\mathrm{CH}_{2} \mathrm{I}_{2}$ and $\mathrm{I}_{2}$; the resulting iodine atoms then react with $\mathrm{O}_{3}$. Iodine monoxide can also promote autocatalyzing reactions. For example IO can react with another IO molecule producing $\mathrm{I}_{2} \mathrm{O}_{2}$ and OIO, a precursor of IOPs (iodine oxide particles) which then accumulate into $\mathrm{CCN}$. IO can also react with other halogens such as $\mathrm{BrO}$ and $\mathrm{ClO}$, which enhances their ozone-depleting potential (Saiz-Lopez et al., 2012).

Photochemical atmospheric reactions transform iodine and organic iodine to iodide $\left(\mathrm{I}^{-}\right)$, iodate $\left(\mathrm{IO}_{3}^{-}\right)$, all of which have been found in atmospheric aerosols (Vogt, 1999). Current models of atmospheric chemistry (McFiggans et al., 2004) indicate that the aerosol $\mathrm{I}^{-}$concentration is negligible due to its transformation into species that revert to the gas phase by reaction with ozone. Instead $\mathrm{IO}_{3}^{-}$is relatively inert and therefore readily accumulates in particles (Pechtl et al., 2006; Saunders et al., 2012b). Iodine speciation in water varies: in anoxic water most of iodine exists as $\mathrm{I}^{-}$, while in oxygenated waters, such as surface $(300 \mathrm{~m})$ ocean water, the dominant species is $\mathrm{IO}_{3}^{-}$. Bluhm et al. (2010) demonstrated that phytoplankton can reduce $\mathrm{IO}_{3}^{-}$to $\mathrm{I}^{-}$, while $\mathrm{UV}$ light can also drive the reduction of $\mathrm{IO}_{3}^{-}$to $\mathrm{I}^{-}$in seawater (Saunders et al., 2012b; Wong, 1991). Doubts remain regarding iodine inorganic speciation in aerosols and which factors are able to control this speciation (Saiz-Lopez and Plane, 2004); UV light and ozone have been proposed to play important roles (Saunders et al., 2012a).

In polar regions bromine is mostly emitted as sea spray aerosol by wave breaking but a connection between bromine and ozone depletion was identified in the 1980s. Oltmans (1981) was the first to observe surface ozone variations on timescales of hours to years. Connections between atmospheric bromine excess and ozone depletions were suggested later when Barrie et al. (1988) measured an "excess of filterable bromine" that could not be explained by windblown sea salt. A strong negative correlation between ozone and bromine was detected suggesting a linear correlation between the two compounds. Bromine-induced ozone depletion events (ODEs) are started by photochemical activation of bromide present in the sea salt causing a cascade of chemical reactions able to drastically reduce the ozone concentration in the boundary layer (Simpson et al., 2007b). It has been suggested that sea-salt bromide is present in young seaice surfaces, frost flowers, snow pack, sea water, and marine aerosols due to its photochemistry which converts $\mathrm{Br}^{-}$ into reactive halogen species (e.g. $\mathrm{Br}$ atoms and $\mathrm{BrO}$ ) that are able to deplete ozone in the remote atmosphere (Simpson et al., 2007a). ODEs are caused by so-called "bromine explosions", a series of photochemical and heterogeneous acid catalyzed reactions. Vogt et al. (1996) proposed a mechanism for bromine activation where sulfur and nitrogen acid species, such as MSA, $\mathrm{SO}_{4}^{2-}$ and $\mathrm{NO}_{\mathrm{x}}$, are able to activate the reactions between ozone and bromide producing the gas phase species $\mathrm{BrO}, \mathrm{Br}_{2}$ and $\mathrm{HOBr}$. The bromine explosion is strongly dependent on $\mathrm{pH}$ because the key reaction of $\mathrm{HOBr}$ with $\mathrm{Cl}^{-}$or $\mathrm{Br}^{-}$is $\mathrm{pH}$ dependent (Ayers et al., 1999; Simpson et al., 2007a). Satellite measurements show enhanced atmospheric bromine oxide $(\mathrm{BrO})$ in the polar spring, coinciding with an ozone minimum measured by ground-based instruments (Simpson et al., 2007a). The bromine explosion may be promoted by the presence of frost flowers that grow above the young sea ice; they are ice crystals of extremely high salinity and are an efficient substrate for the atmospheric emission of chemicals due to their high surface area (Kaleschke et al., 2004). Recently it has also been proposed that fresh snow covering first year sea ice could be a source for gas phase bromine (Pratt et al., 2013).

The current utility of polar ice cores for quantifying sea ice variability is minimal, due to the lack of a sufficiently reliable and specific proxy. Methanesulphonic acid (MSA) has been used to estimate sea ice variations over the last century at Law Dome in coastal Antarctica (Curran et al., 2003); however, this compound is unstable and easily remobilised in the ice matrix after deposition (Smith et al., 2004) limiting its utility for long-term sea ice reconstructions. Further, it has been demonstrated that MSA is not a reliable indicator for sea ice extent at some other coastal sectors of Antarctica (Abram et al., 2011). Sea-salt sodium has also been used to quantify sea ice variations (Wolff et al., 2006) based on the formation of high salinity frost flowers and brine (Rankin et al., 2000) on sea ice surfaces. Such influences are difficult to distinguish from the dominating sodium input from sea spray aerosol (Petit et al., 1999) and open waters have been shown to be the dominant source of sodium deposited at many Antarctic sites, e.g. Law Dome (Curran et al., 1998) and James Ross Island (Abram et al., 2011). 
Even though iodine and bromine species have already been measured in polar snow, to our knowledge no measurement of this species has yet been carried out in Antarctic ice cores. Based on the method developed by Spolaor et al. (2012), we present here the first extended (200 ky) record of iodine and bromine species from the Talos Dome ice core and evaluate the implications of these halogen species for reconstruction of sea ice variability on millennial timescales.

\section{Samples and methods}

\subsection{Ice core samples}

The Talos Dome ice core drilling site $\left(159^{\circ} 4^{\prime} 21^{\prime \prime} \mathrm{E}\right.$, $72^{\circ} 47^{\prime} 14^{\prime \prime} \mathrm{S} ; 2318.5 \mathrm{~m}$ a.s.1.) is located over approximately $1880 \mathrm{~m}$ of ice, the deepest of which has been dated to $250 \mathrm{ky}$ before present (BP) using the TALDICE-1a (Buiron et al., 2011; Schupbach et al., 2011). Featuring a mean annual temperature of $-41^{\circ} \mathrm{C}$ and an average annual accumulation rate of $80 \mathrm{~mm}$ water equivalent, the site is an excellent location for the long-term preservation of climatic signals of southern hemispheric climate change. There are currently only a few ice cores from coastal sites (EPICA-DML, Berkner Island, Taylor Dome, Siple Dome) that record Holocene and post-Holocene climate change or the retreat of the ice sheet since the Last Glacial Maximum (LGM). The coastal position of the Talos Dome (TD) ice core makes this core important for studying marine-related processes during the Antarctic deglaciation. Analyses were conducted on discrete samples of Talos Dome ice sampled for continuous flow analysis (Kaufmann et al., 2008). For each $1 \mathrm{~m}$ long ice sample, $15 \mathrm{~mL}$ was collected in coulter counter accuvettes at a rate of $0.5 \mathrm{~mL} \mathrm{~min}{ }^{-1}$. The samples were kept frozen and shielded from light until analysis.

\subsection{Determination of halogens, sodium and iron}

Iodine $\left(\mathrm{I}^{-}\right.$and $\left.\mathrm{IO}_{3}^{-}\right)$and bromine $\left(\mathrm{Br}^{-}\right)$species were measured at picogram-per-gram levels by coupling highperformance liquid chromatography (HPLC), ion chromatography (IC) and inductively coupled plasma mass spectrometry (ICP-MS). All reagent solutions and samples were prepared in a shipping container converted into a particlefree laboratory. The air qualities ranged from classes 10 to 100 (US Fed. Std 209E, equivalent to ISO 4 to 5). Chromatographic separation was achieved using an IONPAC ${ }^{\circledR}$ AS16 Analytical Column (Dionex, US) with $35 \mathrm{mM} \mathrm{NaOH}$ $99.99 \%$, Sigma-Aldrich (Missouri, USA) eluent. The flow was set to $0.280 \mathrm{~mL}$ per min with a run time of $9 \mathrm{~min}$ and 70 bar operating pressure. The samples were melted without acidification to avoid any $\mathrm{Br}$ or I volatilization and a volume of $0.3 \mathrm{~mL}$ was used for analysis. The detector was an Agilent 7500 series ICP-MS (Agilent, CA, USA) with mono-isotopic I measured at mass 127 and $\mathrm{Br}$ measured at mass 81. Detection limits for $\mathrm{I}$ and $\mathrm{Br}$ species were 5 to $9 \mathrm{pg} \mathrm{g}^{-1}$ with an uncertainty of less than $2.5 \%$ for all considered species. Iodide had a recovery of $80 \%$ while $\mathrm{Br}^{-}$and $\mathrm{IO}_{3}^{-}$had higher recoveries around $90 \%$. For the determination of sodium and iron concentrations, samples were melted and acidified to pH 1 using sub-boiling distilled $\mathrm{HNO}_{3}$ (Romil, Cambridge, UK) and analysed at least $24 \mathrm{~h}$ later by Inductively Coupled Plasma Sector Field Mass Spectrometry (ICP-SFMS; Finnigan $^{\mathrm{TM}}$ ELEMENT2, Thermo Fisher Scientific Inc., Bremen, Germany) coupled to an APEX Q desolvating introduction unit (Elemental Scientific, Omaha, NE, USA). The detection limit of these two elements, defined as three times the standard deviation of the instrument blank, was $0.029 \mathrm{ng}$ $\mathrm{g}^{-1}$, with precisions of $16 \%$ for Holocene samples and $10 \%$ for Last Glacial Maximum (LGM) samples.

\subsection{Iodate stability experiment}

A number of experiments (Table 1 lists the experimental parameters), were conducted to determine if $\mathrm{IO}_{3}^{-}$is unstable in ice under near-UV/visible light irradiation. These experiments were conducted in a photo-chemical flow reactor (PCFR) under conditions described in detail by Saiz-Lopez et al. (2004) and Saunders and Plane (2005). Solar irradiance was simulated between wavelengths 300 to $750 \mathrm{~nm}$ $\left(\lambda_{\max }=583 \mathrm{~nm}\right)$ using a $1000 \mathrm{~W}$ Oriel ${ }^{\circledR}$ Xenon Arc Lamp Solar Simulator (Oriel Instruments, Model 91191) with a water filter for removal of infrared light. The PCFR featured a flow cell with an inner volume of $0.2 \mathrm{~L}$ and equipped with an external cooling jacket filled with methanol (Fig. 1). The flow cell was half filled with $0.1 \mathrm{~L}$ of $10^{-5} \mathrm{M} \mathrm{IO}_{3}^{-}$solution (produced from sodium salt) and subsequently cooled to $-20^{\circ} \mathrm{C}$ until the solution was frozen. The temperature was kept at $-20 \pm 2{ }^{\circ} \mathrm{C}$ for the duration of the experiment $(4 \mathrm{~h})$. The gasphase iodine species produced in the flow cell, resulting from the initial experiment conditions, were then converted into iodine oxide particles (IOPs) in a downstream photolysis cell by the presence of visible light from a tungsten lamp, and $\mathrm{O}_{3}$ (produced by illuminating a flow of $\mathrm{O}_{2}$ with a low pressure $\mathrm{Hg}$ pen ray lamp at $180 \mathrm{~nm}$ ). Briefly, production of IOPs first require the formation of gas phase iodine as IO from the oxidation of $\mathrm{I}_{\text {by }} \mathrm{O}_{3}$; IO then self-reacts to form OIO, which can then go on to form higher oxides which polymerize to generate IOPs (Saunders et al., 2010; Saiz-Lopez et al., 2012). The IOP size distribution, and hence total mass, was measured using an electrical mobility spectrometer (EMS VIE10: Tapcon $\mathrm{GmbH}$ ), consisting of a nano-differential mobility analyzer (nano-DMA) and a Faraday cup electrometer (FCE). Particles were counted in the range from $2 \mathrm{~nm}$ to $40 \mathrm{~nm}$ in diameter.

A $650 \mathrm{sccm}$ (standard cubic centimeter per minute) flow of pure $\mathrm{N}_{2}$ gas was used as the carrier gas for the PCFR system with an $\mathrm{O}_{3}$ concentration of $78 \mathrm{ppbv}$. The gas flow in the flow cell was maintained at $50 \mathrm{sccm}$ of pure $\mathrm{N}_{2}$ except for experiment 4 in which the gas flow was composed of a mixture of $40 \mathrm{sccm}$ of $\mathrm{N}_{2}$ and $10 \mathrm{sccm} \mathrm{O}$, giving a total flux 
Table 1. IOP (iodine oxide particle) production experiment conditions and results. IOP mass productions are expressed as $\mathrm{g} \mathrm{cm}^{-3} \mathrm{measured}$ for $180 \mathrm{~min}(3 \mathrm{~h})$. Abbreviations: Light - solar simulator, $\mathrm{CG}$ - carrier gas, $\mathrm{BF}$ - blue filter, $\mathrm{O}_{3}$ - ozone in the flow cell, $\mathrm{RC}-$ reaction cell, Sol - solutions (W: water, HA: humic acid), an "x" represents an active parameter while "_-" represents an inactive parameter.

\begin{tabular}{llllllll}
\hline Experiment & Light & $\mathrm{CG}$ & $\mathrm{BF}$ & $\mathrm{O}_{3}$ & $\mathrm{RC}$ & Sol & Mass production in 3h \\
\hline 1 & - & $\mathrm{N}_{2}$ & - & - & $\mathrm{x}$ & $10-5 \mathrm{~W}$ & $4.3 \times 10^{-13}$ \\
2 & $\mathrm{x}$ & $\mathrm{N}_{2}$ & - & - & $\mathrm{x}$ & $10-5 \mathrm{~W}$ & $8.5 \times 10^{-13}$ \\
3 & $\mathrm{x}$ & $\mathrm{N}_{2}$ & $\mathrm{x}$ & - & $\mathrm{x}$ & $10-5 \mathrm{~W}$ & $8.5 \times 10^{-13}$ \\
4 & $\mathrm{x}$ & $\mathrm{N}_{2}$ & - & $\mathrm{x}$ & $\mathrm{x}$ & $10-5 \mathrm{~W}$ & $1.0 \times 10^{-12}$ \\
5 & $\mathrm{x}$ & $\mathrm{N}_{2}$ & - & - & $\mathrm{x}$ & $10-5 \mathrm{HA}$ & $3.3 \times 10^{-13}$ \\
6 & $\mathrm{x}$ & $\mathrm{N}_{2}$ & - & - & - & $10-5 \mathrm{~W}$ & $7.1 \times 10^{-13}$ \\
\hline
\end{tabular}

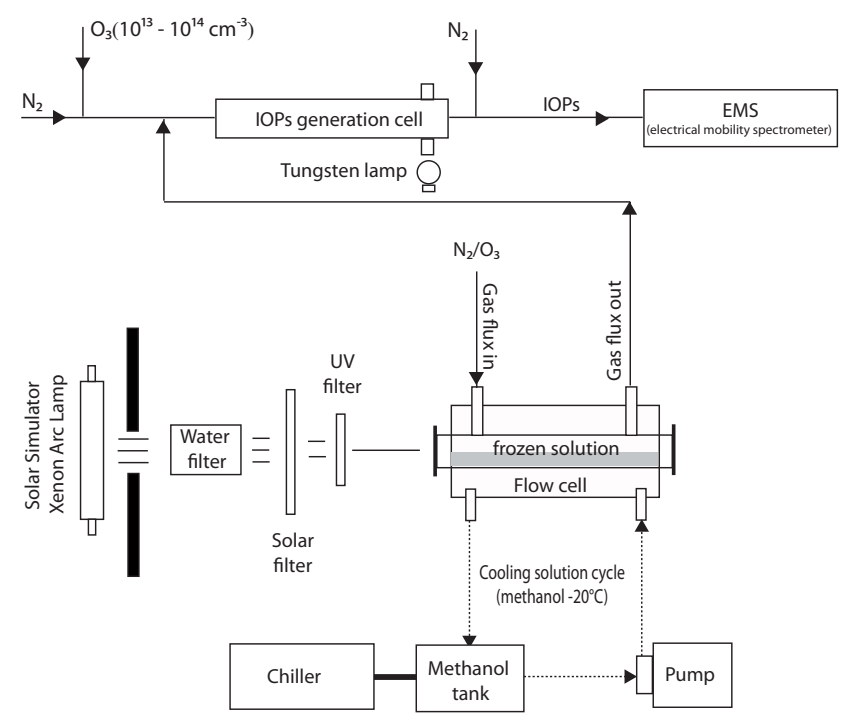

Fig. 1. Schematic diagram of the photochemical flow reactor set up to study the stability/reactivity of $\mathrm{IO}_{3}^{-}$in ice. The solid line represents the gas flow pattern, the dashed line shows the chilled methanol circulation.

of $50 \mathrm{sccm}$. To compare the IOP mass production for each experiment, reported in Table 1, we used the sum of IOPs produced in $180 \mathrm{~min}$ (expressed in $\mathrm{g} \mathrm{cm}^{-3}$ ) while the blank was assessed by repeating the experiment three times using only $\mathrm{N}_{2}$ as carrier gas in the absence of light, thus obtaining a value of $4.3 \pm 1.0 \times 10^{-13} \mathrm{~g} \mathrm{~cm}^{-3}$ (Table 1 )

To avoid potential interference from the presence of other iodine species, all glassware was carefully cleaned with deionized water and a spectrophotometer analysis in the 200$600 \mathrm{~nm}$ range was carried out to ensure the absence of any such species (Fig. 2). The PCFR system was cleaned by fluxing $\mathrm{N}_{2}$ and $\mathrm{O}_{3}$ for $2 \mathrm{~h}$ (the time necessary to reach a stable blank value) thus removing any iodine compounds that may have resided on the inner tube surface. The blank signal was checked before each experiment to ensure that no contaminants were present in the system. Although it has been demonstrated that $\mathrm{IO}_{3}^{-}$is stable in water at least for $30 \mathrm{~h}$ in the absence of humic acid or hydrogen peroxide (Saunders et

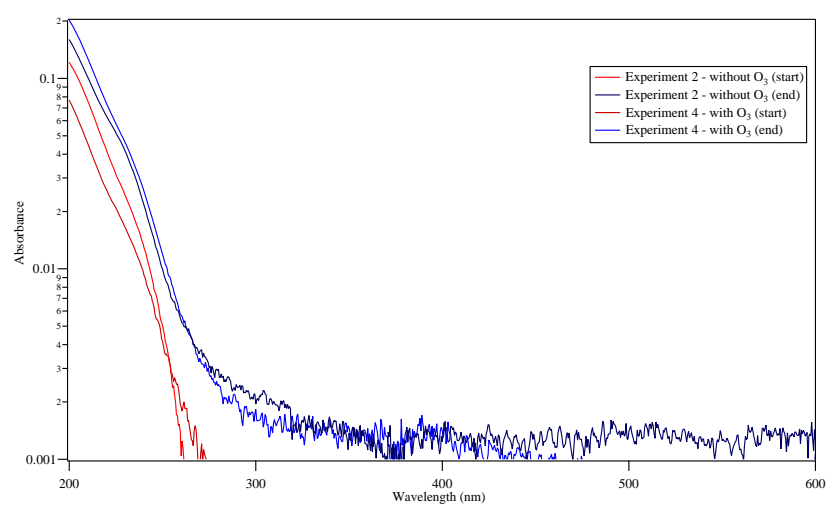

Fig. 2. Results of two iodine oxide particle (IOP) production experiments, showing the spectrophotometric spectra of $10^{-5} \mathrm{M} \mathrm{IO}_{3}^{-}$ solutions in the presence of $\mathrm{O}_{3}$ (experiment 4) and without $\mathrm{O}_{3}$ (experiment 2). Blue lines represent the UV-VIS spectra at the end of the experiment while the red lines show initial conditions (fresh solution). IOPs were produced in both experiments, indicated by the increased absorbance in the range $270-400 \mathrm{~nm}$ where $\mathrm{I}_{3}^{-}$and $\mathrm{I}_{2}$ have absorbance maxima.

al., 2012b), changes in $\mathrm{IO}_{3}^{-}$reactivity have been detected in frozen solutions (Fig. 2).

\subsection{Statistical data analysis}

Confidence intervals for Pearson correlations can be computed with the Fisher $\mathrm{z}$ transformation approach. However, this statistical method requires a pair of variables with a bivariate normal distribution. Such an assumption is not met by TD elemental and species data whose sample distributions differ substantially from the normal shape. A more robust approach for confidence intervals of correlations that does not rely on the normality assumption is the nonparametric bootstrap percentile method (Efron, 1987). The nonparametric bootstrap is a simulation method which consists of random sampling with replacement from the original data in order to quantify uncertainty of a sample estimate, such as the Pearson correlation index. The R package "boot" (Davison and Hinkley, 1997) provides a convenient implementation of 
this simulation approach. In this paper, we employ the nonparametric bootstrap percentile method using 1000 bootstrap replicates.

\section{Results and discussion}

\subsection{Bromide}

Talos Dome (TD) bromide concentrations range from below the detection limit $\left(9 \mathrm{pg} \mathrm{g}^{-1}\right)$ to $200 \mathrm{pg} \mathrm{g}^{-1}$, corresponding to fluxes from $<0.3$ to $17.8 \mu \mathrm{g} \mathrm{m}^{-2} \mathrm{yr}^{-1}$ (Fig. 3). The greatest $\mathrm{Br}^{-}$fluxes occurred during interglacial periods with an average value of $9.5 \mu \mathrm{g} \mathrm{m}^{-2} \mathrm{yr}^{-1}$, while during glacials the average flux decreased to $2.9 \mu \mathrm{g} \mathrm{m}^{-2} \mathrm{yr}^{-1}$ (Fig. 3). The sodium (Na) content was used to evaluate the influence of maritime air masses on Antarctic deposition (Wolff et al., 2006). Na is a conservative element that is not transformed after sea spray emission (Simpson et al., 2005; Ayers et al., 1999), whereas $\mathrm{Br}^{-}$is not stable in sea-salt aerosols and is depleted with respect to seawater (Ayers et al., 1999).

Bromide concentrations in the TD ice core negatively correlate with $\mathrm{Na}$ concentrations (Fig. 3) (hereafter described as correlation $(R)$ equal to $-0.54,95 \%$ confidence interval $(\mathrm{CI})$ equal to $[-0.40,-0.64])$, and are uncorrelated with crustal elements including $\mathrm{Ca}(R=-0.12$; $\mathrm{CI}=[-0.25,0.01]), \mathrm{Fe}(R=-0.10 ; \mathrm{CI}=[-0.23,0.05])$ and $\mathrm{Mn}(R=-0.29 ; \mathrm{CI}=[-0.38,-0.14])$. In contrast to almost all of the other elements in TD ice, $\mathrm{Br}^{-}$correlates $(R=0.79$; $\mathrm{CI}=[0.71,0.84])$ with the $\delta^{18} \mathrm{O}$ temperature proxy (Stenni et al., 2011). The respective correlations between $\mathrm{Br}^{-}$and MSA $(R=-0.1 ; \mathrm{CI}=[-0.23,0.04])$ and $\mathrm{SO}_{4}^{2-}(R=0.03$; $\mathrm{CI}=[-0.15,0.20])$ indicate that glacial-interglacial changes in $\mathrm{SO}_{4}^{2-}$ and MSA are insufficient to modify bromide depletion reaction kinetics.

We use $\mathrm{Na}$ as a sea-salt proxy (Wolff et al., 2010) to calculate the bromide fractionation index $\left(\% \mathrm{Br}_{\mathrm{fi}}\right)$ with respect to sea-salt concentrations using the formula $\% \mathrm{Br}_{\mathrm{fi}}=\left([\mathrm{Na}] \cdot 0.006-\mathrm{Br}_{\text {measured }}\right) \cdot 100 /([\mathrm{Na}] \cdot 0.006)$, which assumes a constant $\mathrm{Br} / \mathrm{Na}$ mass ratio of 0.006 (Millero, 1974) for seawater and fresh sea spray through time (Ayers et al., 1999). The glacial $\% \mathrm{Br}_{\mathrm{fi}}$ is positive, (mean $68 \%$, up to $100 \%$ ) while interglacial $\% \mathrm{Br}_{\mathrm{fi}}$ values are negative (up to $-440 \%$ ) (Fig. 4). Talos Dome $\% \mathrm{Br}_{\mathrm{fi}}$ and sea ice presence (SIP) (Crosta et al., 2004) correlate $(R=0.55$; $\mathrm{CI}=[0.45,0.62])$ and increase $(R=0.65 ; \mathrm{CI}=[0.52,0.73])$ if considering only bromide depletion periods (typically when $\delta^{18} \mathrm{O}<-38.2 \%$ ). SIP and February sea-surface temperatures (SSTs) have been determined by Crosta et al. (2004) using Modern Analog Techniques (MAT $5201 / 31$ ) applied to fossil diatom assemblages in the SO136-111 core, located at $56^{\circ} 40^{\prime} \mathrm{S}$ and $160^{\circ} 14^{\prime} \mathrm{E}$. SIP is expressed as months of sea ice presence per year.

Both investigated glacial cycles (marine isotope stage (MIS) 2, $24 \mathrm{ky} \mathrm{BP,} \mathrm{to} \mathrm{MIS} \mathrm{5c} 105 \mathrm{ky} \mathrm{BP}$, and MIS 6, $150 \mathrm{ky}$

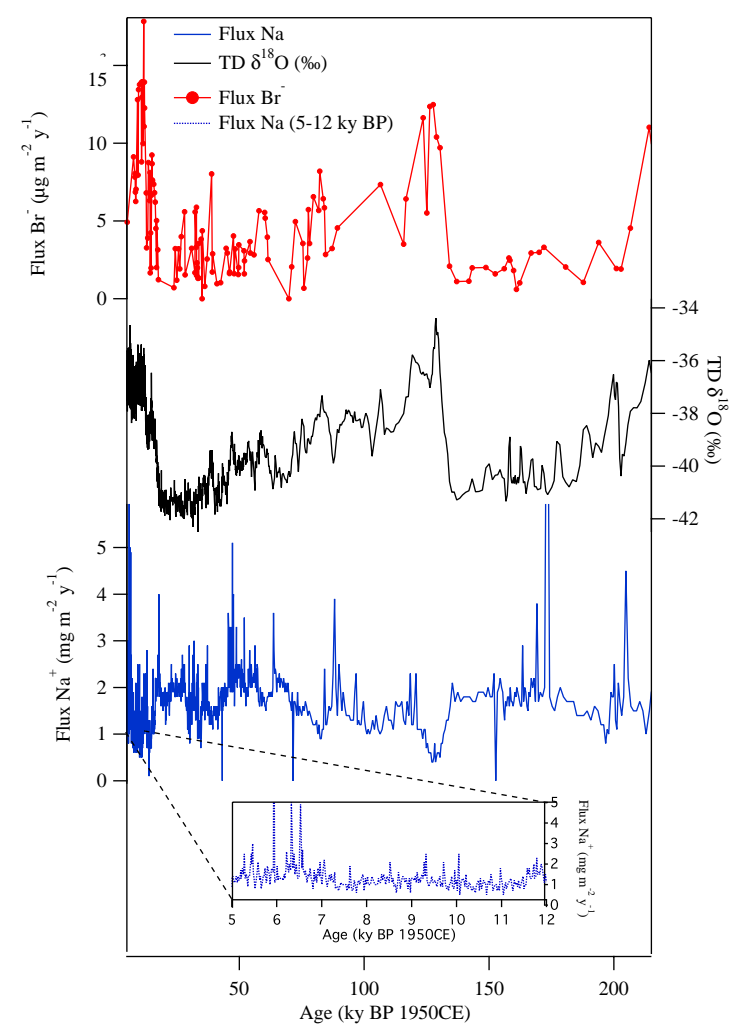

Fig. 3. Plot of $\mathrm{Br}^{-}$fluxes (red) as a function of time in the TD ice core. $\mathrm{Br}^{-}$fluxes correlate with $\delta^{18} \mathrm{O}$ (a proxy for the temperature record - black curve) and anti-correlate with Na fluxes (blue curve). The inset box represents the sodium flux between 6 and $12 \mathrm{ky} \mathrm{BP}$. Note that Sodium and $\delta^{18} \mathrm{O}$ are recorded as a high-resolution data set while bromide was measured at lower resolution.

BP to MIS 7, $240 \mathrm{ky}$ BP) show similar $\% \mathrm{Br}_{\mathrm{fi}}$ values. Factors that may influence $\% \mathrm{Br}_{\mathrm{fi}}$ include the acidity of the aerosols catalyzing the bromide depletion (Ayers et al., 1999; Vogt et al., 1996), and atmospheric residence time which is linked to the distance from source to sink, i.e. sea ice extent.

Bromine explosions cause an excess of total (gas and aerosol phase) bromine compared to sea salt in the atmospheric boundary layer (Simpson et al., 2005). During spring, bromine explosions are favoured at the seasonal sea ice surface by the presence of salts from the freezing seawater process and light mediated activation. The reduced extent of multi-year sea ice during interglacials (present times) implies that bromine explosions are located nearer to the Antarctic coast during such climatic phases. Bromine explosions result in an increased atmospheric $\mathrm{Br}^{-} / \mathrm{Na}$ ratio with respect to seawater (Simpson et al., 2005), and these $\mathrm{Br}^{-}$enriched air masses are then transported by the prevailing winds to TD (Fig. 5). On this basis, we hypothesize that an extended multi-year sea ice surface during glacial periods increased the distance between bromine explosions and the TD ice core site. 


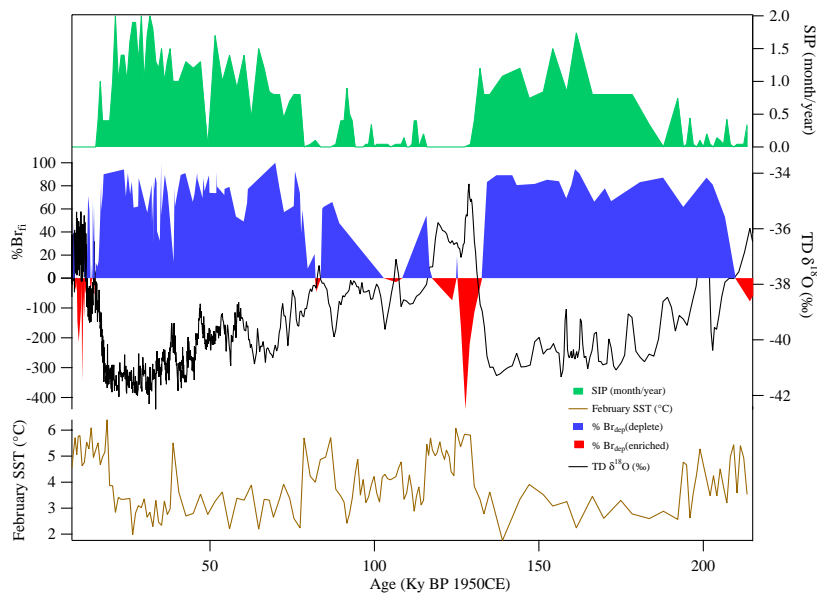

Fig. 4. $\% \mathrm{Br}_{\mathrm{fi}}$ is plotted with sea ice presence (SIP, green area, expressed as month/year) and February sea-surface temperature (red line) (Crosta et al., 2004). Talos Dome $\delta^{18} \mathrm{O}$ is also shown. The red areas indicate $\mathrm{Br}^{-}$enrichment (i.e. negative $\% \mathrm{Br}_{\mathrm{fi}}$ ) while blue areas indicate bromide depletion.

$\mathrm{HBr}$ is the end product of the bromine atmospheric chemistry chain (Vogt et al., 1996). We assume that the deposition velocities of gas-phase $\mathrm{HBr}$ and sea-salt aerosols to the snowpack lead to differential deposition rates as these species are carried inland by cyclonic winds. When seasonal sea ice is located farther from the Antarctic landmass, the increased atmospheric travel time allows the quickly deposited $\mathrm{HBr}$ to deplete relative to atmospheric sea-salt aerosol. Thus the $\mathrm{Br}^{-}$ enhancement observed during interglacial periods changes to a $\mathrm{Br}^{-}$depletion in colder climates because of the reduced proximity to multi-year sea ice. This hypothesis is supported by $\mathrm{Br}^{-}$and $\mathrm{Na}$ measurements in inland interglacial EPICA Dome C $\left(75^{\circ} 06^{\prime} \mathrm{S}, 123^{\circ} 21^{\prime} \mathrm{E}\right.$; $\mathrm{m}$ a.s.l. 3233) ice core samples showing small depletions of $\mathrm{Br}\left(\% \mathrm{Br}_{\mathrm{fi}}=14 \%\right)$ compared to an enrichment of $-63 \%$ detected in TD ice.

If $\mathrm{Br}^{-} / \mathrm{Na}$ ratios and $\% \mathrm{Br}_{\mathrm{fi}}$ are linked with air mass travel times it is important to consider changes in atmospheric circulation between cold and warm periods. Hemispheric-scale models, as well as observations of dust particle sizes, indicate only modest changes in surface winds, atmospheric circulation, and meridional transport over Antarctica between glacial and interglacial climates (Petit and Delmonte, 2009; Fischer et al., 2007). Although the deglacial retreat of the Ross Ice Shelf has been related to activation of local dust deflation zones (Albani et al., 2012), it has been observed that only $25 \%$ of air mass trajectories arriving at TD originate from this sector: the majority of air masses at TD originate from the westerly Atlantic-Indian Ocean sector (Scarchilli et al., 2011). The constant $\mathrm{Na}$ fluxes observed throughout the Holocene at TD (Fig. 3) are indicative of a constant flux of marine air masses during this period, suggesting that any deglacial changes to regional atmospheric circulation did not considerably affect the influence of marine air masses on TD.

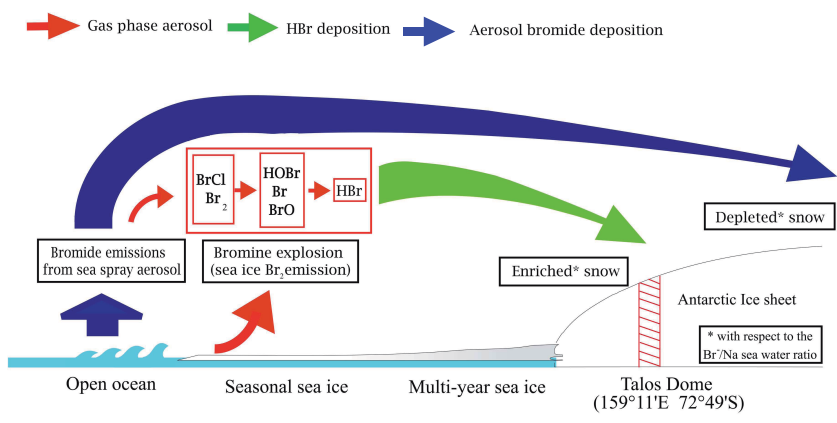

Fig. 5. Simplified scheme for bromide aerosol deposition in coastal Antarctica. Blue lines indicate the aerosol phase while red lines indicate the gas phase. Green line the $\mathrm{HBr}$ deposition.

\section{Bromide model calculation and outcome}

The purpose of the modelling described in this section is to provide a plausible explanation for the variation in $\% \mathrm{Br}_{\mathrm{fi}}$ measured at Talos Dome over several glacial cycles. It is not possible to demonstrate unambiguously that the variation in sea-ice extent caused these variations by using a simple 1-D transport model where several parameters are poorly known (as discussed below). Rather, our objective is to show that by choosing sensible values of these parameters it is possible to explain the variations in $\% \mathrm{Br}_{\mathrm{fi}}$ levels, and thus to estimate the change in the sea-ice extent between glacial and interglacial periods.

The Tropospheric HAlogen chemistry MOdel (THAMO) is a 1-D chemistry transport model (Saiz-Lopez et al., 2008) with 200 stacked boxes at a vertical resolution of $1 \mathrm{~m}$ (total height $200 \mathrm{~m}$ ). The model was developed to interpret measurements made at Halley Bay (Antarctica) of IO and $\mathrm{BrO}$ in the coastal boundary layer (Saiz-Lopez et al., 2007b). The model treats iodine, bromine, $\mathrm{O}_{3}, \mathrm{NO}_{\mathrm{x}}$ and $\mathrm{HO}_{\mathrm{x}}$ chemistry using over 210 reactions. The chemical scheme is from SaizLopez et al. (2008) and has been updated by Mahajan et al. (2010). The model is used here to follow the evolution of the halogens in an air parcel which crosses the multi-year sea-ice edge and then travels across the sea ice and coastal margin to Talos Dome. If the average wind speed is $9 \mathrm{~m} \mathrm{~s}^{-1}$ (Scarchilli et al., 2011), then it would take about $7 \mathrm{~h}$ to transport air from the sea-ice edge to Talos Dome $(\sim 230 \mathrm{~km})$. This corresponds to the interglacial situation. During glacial times, the air would travel about $780 \mathrm{~km}$ in $24 \mathrm{~h}$, which is similar to the distance from the sea-ice edge to Dome $\mathrm{C}$ at present (Scarchilli et al., 2011).

The following conditions were used, mostly based on the extensive CHABLIS field campaign at Halley Bay (Jones et al., 2008). This coastal Antarctic station is roughly $20 \mathrm{~km}$ from the sea ice edge, and so the large suite of atmospheric chemistry and physics measurements made during CHABLIS should be appropriate for the present modeling exercise. The temperature was set to $250 \mathrm{~K}$ at the base of 
the boundary layer, and the vertical eddy diffusion coefficient $\left(K_{z}\right)$ was set to be constant $\left(3 \times 10^{4} \mathrm{~cm}^{2} \mathrm{~s}^{-1}\right)$, based on the wind speed vertical profile at Halley (Saiz-Lopez et al., 2008). The model was constrained with typical measured values of the following species which interact directly with halogens: $\left[\mathrm{O}_{3}\right]=30 \mathrm{ppb} ;\left[\mathrm{NO}_{\mathrm{x}}\right]=25 \mathrm{ppt}$; $[\mathrm{DMS}]=$ $80 \mathrm{ppt} ;\left[\mathrm{CH}_{3} \mathrm{CHO}\right]=200 \mathrm{ppt} ;[\mathrm{HCHO}]=200 \mathrm{ppt}(\mathrm{Read}$ et al., 2007). The modelled $\mathrm{HO}_{\mathrm{x}}$ concentrations $([\mathrm{OH}]=$ $1.3 \times 10^{6} \mathrm{~cm}^{-3},\left[\mathrm{HO}_{2}\right]=1.7 \times 10^{8} \mathrm{~cm}^{-3}$ at midday) are in sensible accord with measured values at Halley Bay (SaizLopez et al., 2008).

The initial sea-salt aerosol loading was set to 40 particles $\mathrm{cm}^{-3}$ of $0.5 \mu \mathrm{m}$ diameter, providing a volumetric particle surface area of $3.0 \times 10^{-7} \mathrm{~cm}^{2} \mathrm{~cm}^{-3}$ and a volumetric particle volume of $2.6 \times 10^{-15} \mathrm{dm}^{3} \mathrm{~cm}^{-3}$. The corresponding mass concentration is $2600 \mathrm{ng} \mathrm{m}^{-3}$. This concentration is somewhat higher than the $4 \mathrm{yr}$ average of $1400 \mathrm{ng} \mathrm{m}^{-3}$ measured at the coastal Antarctic station of Dumont D'Urville, which was stated to be a lower limit because of sampling size cut-offs (Wagenbach et al., 1998). The prevailing wind at Dumont D'Urville is directly onshore (average $9.5 \mathrm{~m} \mathrm{~s}^{-1}$ ) and the station is on a small island, and so provides a reasonably close match to the model scenario. The initial $\mathrm{Br}^{-}$concentration was assumed to be that of seawater, $65 \mathrm{mg} \mathrm{L}^{-1}$, so the $\mathrm{Br}^{-} / \mathrm{Na}^{+}$elemental ratio was $1.5 \times 10^{-3}$. The deposition velocities of $\mathrm{HBr}$ and $\mathrm{HI}$ to the snowpack were set to $1 \mathrm{~cm} \mathrm{~s}^{-1}$. This would be typical for a hydrophilic acidic gas (e.g. $\mathrm{HNO}_{3}$ ) at an average wind speed of $9 \mathrm{~m} \mathrm{~s}^{-1}$ over a smooth surface (Ma and Daggupaty, 2000). The deposition velocity of the sea-salt aerosol was set to $0.2 \mathrm{~cm} \mathrm{~s}^{-1}$. The deposition velocity is quite size dependent (being larger than $0.2 \mathrm{~cm} \mathrm{~s}^{-1}$ for particles smaller than $0.1 \mu \mathrm{m}$ or larger than $4 \mu \mathrm{m}$, and reaching a minimum of about $0.1 \mathrm{~cm} \mathrm{~s}^{-1}$ for $2 \mu \mathrm{m}$ diameter particles (Ma and Daggupaty, 2000)). This deposition velocity therefore represents an average over the sea-salt size distribution, and is treated as a fitted parameter in the model. This combination of deposition velocity and $K_{z}$ profile in the model gives an e-folding lifetime for the removal of sea-salt aerosol from the BL of around $30 \mathrm{~h}$.

The ice core record contains the integrated annual accumulation of $\mathrm{Br}^{-}$and $\mathrm{Na}$. The annual $\mathrm{BrO}$ record in the boundary layer at Halley Bay exhibits active springtime bromine explosion chemistry averaging around $10 \mathrm{ppt}$ of $\mathrm{BrO}$, less bromine in the summer and autumn (around $4 \mathrm{ppt}$ ), and essentially nothing during the polar night (Saiz-Lopez et al., 2007b). In order to account for this seasonal variation, 1 ppt of $\mathrm{Br}_{2}$ was injected into the first $40 \mathrm{~m}$ of the boundary layer at time zero, when the air parcel crossed the sea-ice edge. This injection simulated the effect of a time-averaged "bromine explosion". An $\mathrm{I}_{2}$ flux of $7 \times 10^{7} \mathrm{~cm}^{-2} \mathrm{~s}^{-1}$ was required to generate an IO concentration of 1-2 ppt while the air parcel was over the sea ice (cf. a flux of $5 \times 10^{8} \mathrm{~cm}^{-2} \mathrm{~s}^{-1}$ is required to generate the average of $6 \mathrm{ppt}$ measured at Halley during summer (Saiz-Lopez and Boxe, 2008). The uptake of iodine species

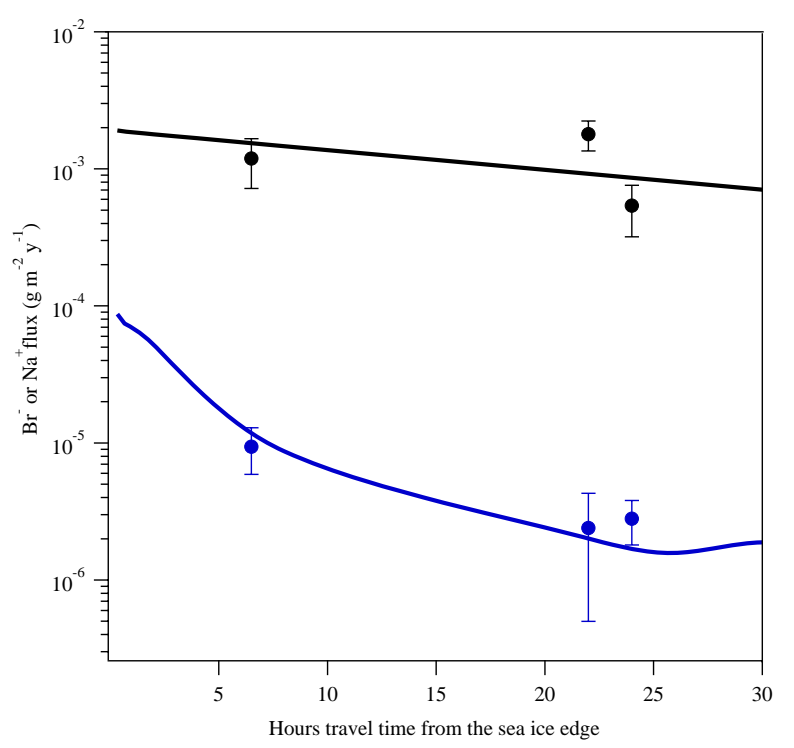

Fig. 6. Comparison between the modelled deposition fluxes for sodium (black) and bromide (blue) with measurements at Talos Dome (Circles, $7 \mathrm{~h}$ from sea ice edge) and Dome C (Circles, 22 and $24 \mathrm{~h}$ from sea ice edge).

such as $\mathrm{HOI}$ and $\mathrm{IONO}_{2}$ on sea-salt aerosol converts aerosol bromide into gas-phase $\mathrm{BrO}$, etc.

Figure 6 compares the modelled deposition fluxes with the measurements at Talos Dome and Dome $\mathrm{C}$, using the travel times from the sea ice edge (Talos Dome $=7 \mathrm{~h}$ during interglacials, $22 \mathrm{hrs}$ during glacial; Dome $\mathrm{C}=24 \mathrm{~h}$ during interglacials). Using the assumptions listed above, good agreement is achieved between this simple model and the measured fluxes. An important conclusion is that, for the model to predict the change in $\mathrm{Br}_{\text {dep }}$ with travel time from the seaice edge, the deposition velocity of $\mathrm{HBr}$ needs to be at least 3 times larger than the average sea-salt aerosol deposition velocity, which is consistent with dry deposition theory and measurement (Ma and Daggupaty, 2000). While there are too many assumed parameters in the model to constrain them rigorously, the purpose of this exercise is to show that the observed changes in fluxes are plausibly explained by a change in the distance of the sea-ice edge from the continent.

Our model calculations demonstrate the dependence of $\mathrm{Br}^{-} / \mathrm{Na}$ ratios on air mass transport times where the transition from $\mathrm{Br}$ enrichment to depletion is approximately 8-9 h (Fig. 7). Considering an average air-mass speed of $850 \mathrm{~km} \mathrm{day}^{-1}$ (Scarchilli et al., 2011) and the average Holocene $\% \mathrm{Br}_{\mathrm{fi}}$ value $(-60 \%)$, we calculate that the air masses travelled approximately $300 \mathrm{~km}$, the distance between TD and the coast. The $70 \%$ depletion observed during glacial times would require a travel time of $700-800 \mathrm{~km}$ suggesting that the young sea ice was likely located $500 \mathrm{~km}$ farther north than the interglacial extent, which is consistent 


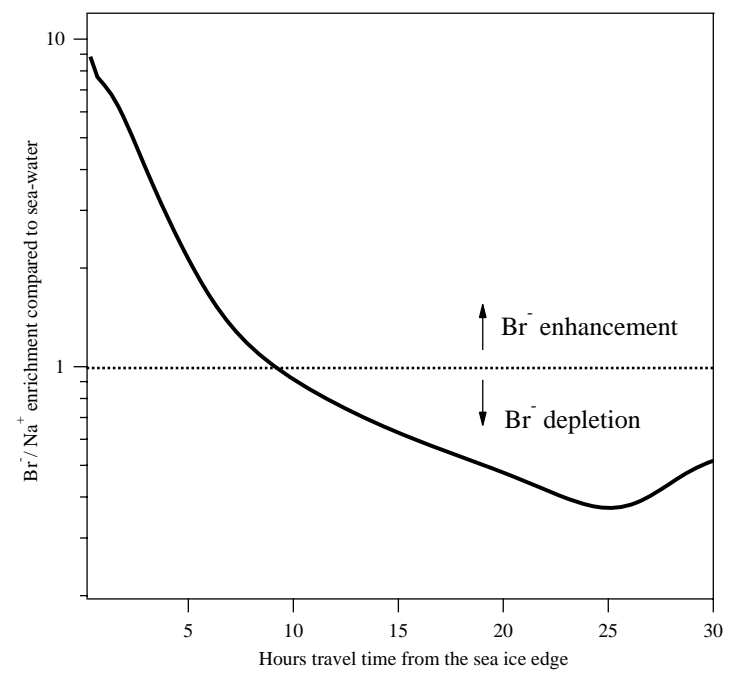

Fig. 7. Variability in the observed $\mathrm{Br} / \mathrm{Na}$ ratios expressed as a function of the air mass travel time due to the different deposition velocities of $\mathrm{HBr}$ and sea salt in the model. After $8 \mathrm{~h}$ of transport, bromide begins to be depleted relative to sea salt.

with other estimates of the Antarctic sea ice in the literature (Gersonde et al., 2005).

\subsection{Iodine}

\subsubsection{Total iodine}

Iodine speciation can also provide information on sea ice (Atkinson et al., 2012). In contrast to $\mathrm{I}_{2}$ and iodocarbons produced from algae on the underside of sea ice (Saiz-Lopez et al., 2007b; Saiz-Lopez and Boxe, 2008), sea-salt iodine (ss-I) accounts for less than 1\%. The total iodine deposition flux $\left(\mathrm{I}_{\text {tot }}=\mathrm{IO}_{3}^{-}+\mathrm{I}^{-}\right)$was highest during glacial periods, with a mean of $3.2 \mu \mathrm{g} \mathrm{m}^{-2} \mathrm{yr}^{-1}$ and values up to $11.2 \mu \mathrm{g} \mathrm{m}^{-2} \mathrm{yr}^{-1}$ during the LGM, compared to the interglacial average of $1.1 \mathrm{\mu g} \mathrm{m}^{-2} \mathrm{yr}^{-1}$ (Fig. 8). Increased iodine fluxes during glacials are consistent with a greater seasonal sea ice area colonized by algae. This connection is also supported by anti-correlations between $\mathrm{I}_{\text {tot }}$ and $\delta^{18} \mathrm{O}(R=$ $-0.55 ;[-0.66,-0.34])$ and correlations between $\mathrm{I}_{\text {tot }}$ and sea ice presence $(\mathrm{SIP})(\mathrm{R}=0.65 ; \mathrm{CI}=[0.53,0.73])$ (Crosta et al., 2004).

While the iodine record is consistent with the Antarctic spring sea ice extension (Schönhardt et al., 2012), other factors may have contributed to the glacial-interglacial changes in $\mathrm{I}_{\text {tot }}$. Such factors include dust-induced ocean fertilization (Martin, 1990) and potential algal population changes. The iodine fluxes doubled between the two investigated glacial periods: $3.6 \mu \mathrm{g} \mathrm{m}^{-2} \mathrm{yr}^{-1}$ (MIS 2 to MIS 5) and $1.6 \mu \mathrm{g} \mathrm{m}^{-2} \mathrm{yr}^{-1}$ (MIS 6 to MIS 7), and correspond to dust flux changes and therefore the potential aeolian nutrient supply. We evaluated correlations between $\mathrm{I}_{\text {tot }}$ flux and Fe (aeo-

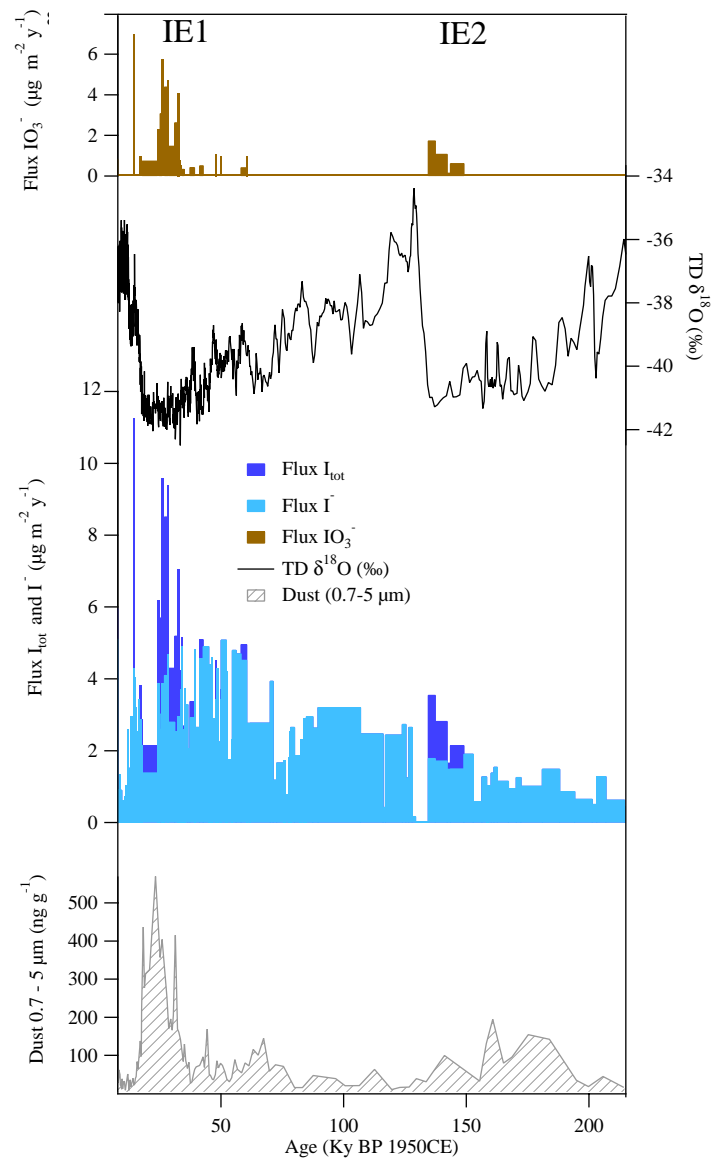

Fig. 8. Iodate $\left(\mathrm{IO}_{3}^{-}\right.$, brown), iodide $\left(\mathrm{I}^{-}\right.$, light blue $)$and total iodine ( $\mathrm{I}_{\text {tot }}$, blue) in Talos Dome ice core samples. While $\mathrm{I}^{-}$is present in all samples, $\mathrm{IO}_{3}^{-}$is closely linked with the fine dust load (grey shaded area, Delmonte et al., 2004) and is present only from 16.8 to $33.8 \mathrm{ky} \mathrm{BP}$ and 134.2 to $143.2 \mathrm{ky} \mathrm{BP}$.

lian nutrient supply, $R=0.25 ; \mathrm{CI}=[0.05,0.48]), \operatorname{MSA}(R=$ $-0.15 ; \mathrm{CI}=[-0.31,0.01])$ and non-sea-salt sulfate (nss$\left.\mathrm{SO}_{4}, R=-0.06 ; \mathrm{CI}=[-0.19,0.10]\right)$. Aeolian ocean fertilization appears to impact atmospheric iodine concentrations less than the influence of sea ice extent. The differences between the two glacial stages may also be due to the slightly warmer glacial between MIS 5 to 7 (mean $\delta^{18} \mathrm{O}-40.1 \%$ ) compared to MIS 2 to 4 (mean $\delta^{18} \mathrm{O}-40.6 \%$ ) (Stenni et al., 2011). These local temperature data agree with the LR04 global benthic marine stack (Lisiecki and Raymo, 2005) as a proxy for global ice volume. Assuming a linear relation between sea ice and $\mathrm{I}_{2}$ production, we calculate that the LGM summer sea ice extent was approximately double that of the penultimate glacial maximum.

\subsubsection{Iodine speciation and iodate reactivity}

Iodate is the most stable iodine species in the atmosphere (Saiz-Lopez et al., 2012; Pechtl et al., 2006) although the 


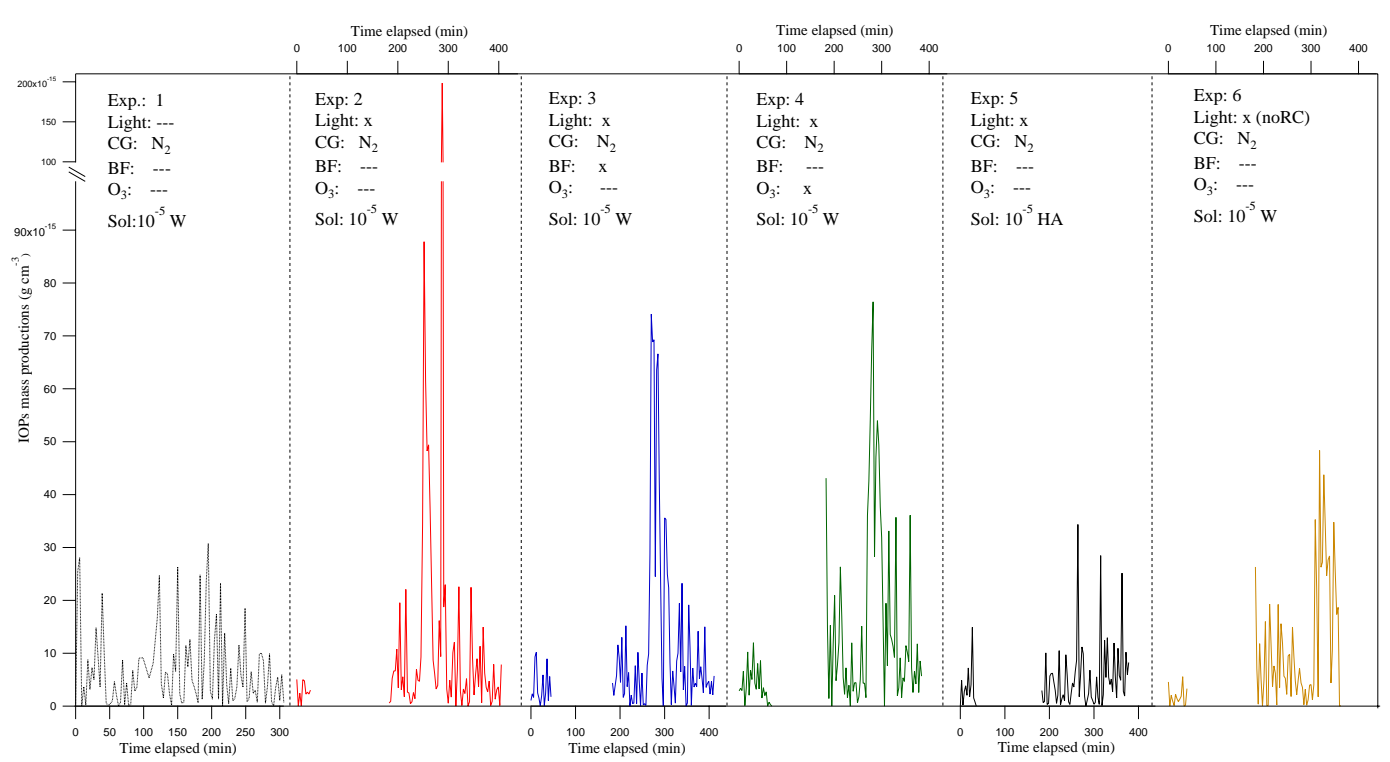

Fig. 9. Rates of IOP particle production (in $\mathrm{g} \mathrm{cm}^{-3}$ ) from the frozen $\mathrm{IO}_{3}^{-}$solutions under different experimental conditions as summarised in Table 1. The blank is shown at the beginning of each experiment. Abbreviations: Light - solar simulator, CG - carrier gas, BF - blue filter, $\mathrm{O}_{3}$ - ozone in the flow cell, $\mathrm{RC}$ - reaction cell, Sol - solutions (W: water, HA: humic acid). An "x" represents an active parameter while "_," represents an inactive parameter.

atmospheric iodate/iodide ratio is variable (Baker, 2004; Gilfedder et al., 2008). Iodide is present throughout the TD record, from interglacial fluxes of $1.1 \mu \mathrm{g} \mathrm{m}^{-2} \mathrm{yr}^{-1}$ to glacial fluxes of $2.9 \mathrm{\mu g} \mathrm{m}^{-2} \mathrm{yr}^{-1}$, while $\mathrm{IO}_{3}^{-}$is only present above the detection limit during the glacial maxima (Fig. 8). Two iodate horizons between 16.8-33.8 ky BP and 134.2$143.2 \mathrm{ky}$ BP contain concentrations up to 30 times more than the detection limit. Observational evidence (Baker et al., 2001) and model calculations (Pechtl et al., 2006; Saunders et al., 2012b) suggest that $\mathrm{IO}_{3}^{-}$should accumulate in marine aerosol while iodide should be considered negligible due to its transformation into species that revert to the gas phase after reaction with hypohalous acids $(\mathrm{HOX}, \mathrm{X}=\mathrm{Cl}$, $\mathrm{Br}, \mathrm{I})$ to form volatile IX (Baker, 2004) by reaction cycles proposed by Vogt et al. (1999). However, disagreement exists between observations of the atmospheric ratio of $\mathrm{I}^{-} / \mathrm{IO}_{3}^{-}$, where a study from the tropical Atlantic Ocean detected a majority of $\mathrm{IO}_{3}^{-}$and negligible $\mathrm{I}^{-}$(Saiz-Lopez and Plane, 2004) whereas another study found non-negligible $\mathrm{I}^{-}$concentrations in aerosols (Baker, 2004). Although $\mathrm{IO}_{3}^{-}$has been considered an inert inorganic iodine species our results suggest substantial reactivity. In Talos Dome ice samples, $\mathrm{IO}_{3}^{-}$ is present only during glacial maxima when dust fluxes were at their maximum and temperatures were at their minimum, while iodide is present in all samples. These observations suggest that in polar ice $\mathrm{I}^{-}$is the more stable species, while $\mathrm{IO}_{3}^{-}$is present only under particular conditions.

Considering the results of the $\mathrm{IO}_{3}^{-}$stability experiments, it was found that IOPs were produced from aqueous solutions (experiments 2, 3, 4 and 6), but not from humic acid solu- tions (experiment 5), in the presence of light (Fig. 9). IOP formation results from the release of iodine gas compounds (likely HOI, IO and $\mathrm{I}_{2}$ ) from the frozen solution surface indicating reduction of $\mathrm{IO}_{3}^{-}$has occurred. It is important to note that only $\mathrm{IO}_{3}^{-}$was dissolved in deionized water, so the $\mathrm{IO}_{3}^{-}$ reduction must have been photochemically driven. Though $\mathrm{IO}_{3}^{-}$in aqueous media absorbs light only in the UV range (Awtrey and Connick, 1951) at wavelengths below $270 \mathrm{~nm}$ (Fig. 2), theoretical calculations indicate the photochemical threshold for the reaction $\mathrm{IO}_{3}^{-}+v v \rightarrow \mathrm{IO}(\mathrm{g})+\mathrm{O}_{2}^{-}$in ice is $315 \mathrm{~nm}$ which is consistent with the large IO concentration which has been observed spectroscopically within the polar snow pack (Frieß et al., 2010). In the presence of light, our experiments demonstrate the greatest IOP production, $1.0 \times 10^{-12} \mathrm{~g} \mathrm{~cm}^{-3}$, with $\mathrm{O}_{3}$ present in the $\mathrm{N}_{2}$ carrier gas and the RC activated. The lowest IOP production occurred when the RC was not activated $\left(7.1 \times 10^{-13} \mathrm{~g} \mathrm{~cm}^{-3}\right)$. Similar intermediate levels of mass production, $8.5 \times 10^{-12} \mathrm{~g} \mathrm{~cm}^{-3}$, were obtained in experiments 2 and 3 where the only difference was the absence of light of $\lambda>310 \mathrm{~nm}$ in experiment 3 . This demonstrates that, under the experimental conditions, visible light did not contribute to IOP production.

It is evident from these experiments that the release of gasphase iodine from frozen $\mathrm{IO}_{3}^{-}$solutions can occur, however it is difficult to distinguish which type of inorganic iodine was formed. Considering the UV-VIS spectra (Fig. 2) before and after irradiation it is likely that $\mathrm{I}_{2}$ was present, as suggested by the increased absorbance in the range $270-400 \mathrm{~nm}$ where $I_{3}^{-}$and $I_{2}$ have absorbance maxima. The presence of other iodine gas species such as IO and OIO is suggested by a 
comparison of the results of experiments 2 and 3 with experiment 6 , in which the $\mathrm{RC}$ was deactivated. If only $\mathrm{I}_{2}$ was produced no IOP formation would be possible since both ozone and visible light are necessary to convert $\mathrm{I}_{2}$ to IOPs. As previously noted, IO and OIO are able to produce IOPs in the absence of $\mathrm{O}_{3}$ and visible light. The presence of IO and OIO is suggested by the difference in mass production between the blank $\left(4.3 \times 10^{-13} \mathrm{~g} \mathrm{~cm}^{-3}\right)$ and experiment $6\left(7.1 \times 10^{-13}\right.$ $\mathrm{g} \mathrm{cm}^{-3}$ ), in which light was present but the reaction cell was deactivated. The possibility exists that $\mathrm{IO}_{3}^{-}$could be reduced to these forms and then dissolve in the liquid water present in ice crystal boundaries (Sazaki et al., 2012). This could explain the fact that the production of IOPs and hence the release of gas-phase iodine from ice is not uniform but presents an increase after at least 100 min (Fig. 9) suggesting a complex chemistry and diffusion of $\mathrm{I}_{2}$ and likely IO through the matrix.

In light of these experiments we propose that $\mathrm{IO}_{3}^{-}$, though it has been found stable in liquid water, is not stable in ice and is photoreduced to other iodine species, principally IO and $\mathrm{I}_{2}$ but with the possibility of also other species such as $\mathrm{I}^{-}, \mathrm{I}_{3}^{-}$and OIO. Regarding the presence of $\mathrm{IO}_{3}^{-}$only in the dusty and cold glacial climate periods, it seems that increased dust fluxes (from $1-2 \mathrm{mg} \mathrm{m}^{-2} \mathrm{yr}^{-1}$ during interglacials to $15-20 \mathrm{mg} \mathrm{m}^{-2} \mathrm{yr}^{-1}$ during glacials, Lambert et al., 2008) favour the formation of metal iodates by interactions of gas phase iodine oxide molecules and dust and, together with decreasing temperature $\left(10^{\circ} \mathrm{C}\right.$ lower from interglacial to glacial, Petit et al., 1999) could promote greater $\mathrm{IO}_{3}^{-}$stability. The correlation $(R=0.77)$ obtained between $\mathrm{IO}_{3}^{-}$and fine dust $(0.7-5 \mu \mathrm{m})$ (Delmonte et al., 2004) suggests that during glacial periods gas-phase molecules such as $\mathrm{I}_{2} \mathrm{O}_{4}$ attach to dust particles during transport.

\section{Conclusions}

We report the first bromine and iodine concentrations in ice cores as well their speciation. Based on the presented data and our simple $\mathrm{Br}$ depletion model, we estimate that glacial multi-year sea ice extended $\sim 500 \mathrm{~km}$ north of the Antarctic coast, with maximum extension from 16 to $80 \mathrm{ky} \mathrm{BP}$ and 134 to $205 \mathrm{ky}$ BP. This interpretation is also consistent with the increased iodine fluxes observed during glacial periods, which imply an approximate doubling of LGM winter sea ice extent compared to the penultimate glacial maximum. In addition, our results seem to suggest a reduction of iodate after deposition that could lead to iodide formation. Further studies should be carried out at other coastal and inland stations of Antarctica to compare with the results presented here.

It is now well known that bromine and iodine chemistry are particularly active in the polar atmosphere and have been linked by satellite observations to Antarctic sea ice, as opposed to the interior of Antarctica where background levels are observed (Schönhardt et al., 2012). This may be due to the temperature dependence of bromine activation (Oldridge and Abbatt, 2011), in which the lower temperatures of the Antarctic plateau (TD mean temperature $-41^{\circ}$ ) (Frezzotti et al., 2004) reduce the reactivity of bromine and iodine. It is important to further study the depositional and postdepositional chemical processes of halogens in polar ice to confirm the validity of these species as long-term proxies of sea ice location and extent.

Acknowledgements. We thank Roberto Udisti for TALDICE MSA and $\mathrm{SO}_{4}^{2-}$ data. This work was supported by European Union Marie Curie IIF Fellowship (MIF1-CT-2006-039529, TDICOSO) within the VII Framework Program. The Talos Dome Ice Core Project (TALDICE), a joint European programme, is funded by national contributions from Italy, France, Germany, Switzerland and the United Kingdom. Primary logistical support was provided by PNRA at Talos Dome. This is TALDICE publication no 29 .

Edited by: R. Ebinghaus

\section{References}

Abram, N. J., Mulvaney, R., and Arrowsmith, C.: Environmental signals in a highly resolved ice core from James Ross Island, Antarctica, J. Geophys. Res., 116, D20116, doi:10.1029/2011jd016147, 2011.

Albani, S., Delmonte, B., Maggi, V., Baroni, C., Petit, J.-R., Stenni, B., Mazzola, C., and Frezzotti, M.: Interpreting last glacial to Holocene dust changes at Talos Dome (East Antarctica): implications for atmospheric variations from regional to hemispheric scales, Clim. Past, 8, 741-750, doi:10.5194/cp-8-7412012, 2012.

Atkinson, H. M., Huang, R.-J., Chance, R., Roscoe, H. K., Hughes, C., Davison, B., Schönhardt, A., Mahajan, A. S., Saiz-Lopez, A., Hoffmann, T., and Liss, P. S.: Iodine emissions from the sea ice of the Weddell Sea, Atmos. Chem. Phys., 12, 11229-11244, doi:10.5194/acp-12-11229-2012, 2012.

Awtrey, A. D. and Connick, R. E.: The Absorption Spectra of I2, I3, I-, IO3-, S4O6= and S2O3=. Heat of the Reaction I3- $=\mathrm{I} 2+$ I, J. Am. Chem. Soc., 73, 1842-1843, doi:10.1021/ja01148a504, 1951.

Ayers, G. P., Gillett, R. W., Cainey, J. M., and Dick, A. L.: Chloride and Bromide Loss from Sea-Salt Particles in Southern Ocean Air, J. Atmos. Chem., 33, 299-319, doi:10.1023/a:1006120205159, 1999.

Baker, A. R.: Inorganic iodine speciation in tropical Atlantic aerosol, Geophys. Res. Lett., 31, L23S02, doi:10.1029/2004g1020144, 2004.

Baker, A., Tunnicliffe, C., and Jickells, T.: Iodine speciation and deposition fluxes from the marine atmosphere, J. Geophys. Res., 106, 28743, doi:10.1029/2000JD000004, 2001.

Barrie, L. A., Bottenheim, J. W., Schnell, R. C., Crutzen, P. J., and Rasmussen, R. A.: Ozone destruction and photochemical reactions at polar sunrise in the lower Arctic atmosphere, Nature, 334, 138-141, 1988. 
Bluhm, K, Croot, P., Wuttig, K., and Lochte, K.: Transformation of iodate to iodide in marine phytoplankton driven by cell senescence, Aquat. Biol., 11, 1-15, doi:10.3354/ab00284, 2010.

Buiron, D., Chappellaz, J., Stenni, B., Frezzotti, M., Baumgartner, M., Capron, E., Landais, A., Lemieux-Dudon, B., MassonDelmotte, V., Montagnat, M., Parrenin, F., and Schilt, A.: TALDICE-1 age scale of the Talos Dome deep ice core, East Antarctica, Clim. Past, 7, 1-16, doi:10.5194/cp-7-1-2011, 2011.

Carpenter, L. J., MacDonald, S. M., Shaw, M. D., Kumar, R., Saunders, R. W., Parthipan, R., Wilson, J., and Plane, J. M. C.: Atmospheric iodine levels influenced by sea surface emissions of inorganic iodine, Nature Geosci., 6, 108-111, 2013.

Crosta, X., Sturm, A., Armand, L., and Pichon, J.-J.: Late Quaternary sea ice history in the Indian sector of the Southern Ocean as recorded by diatom assemblages, Mar. Micropaleontol., 50, 209-223, 2004

Curran, M. A. J., Van Ommen, T. D., and Morgan, V.: Seasonal characteristics of the major ions in the high-accumulation Dome Summit South ice core, Law Dome, Antarctica, Ann. Glaciol., 27, 385-390, 1998.

Curran, M. A. J., van Ommen, T. D., Morgan, V. I., Phillips, K. L., and Palmer, A. S.: Ice Core Evidence for Antarctic Sea Ice Decline Since the 1950s, Science, 302, 1203-1206, 2003.

Davison, A. C. and Hinkley, D. V.: Bootstrap Methods and Their Applications, Cambridge University Press, Cambridge, 1997.

Delmonte, B., Basile-Doelsch, I., Petit, J. R., Maggi, V., RevelRolland, M., Michard, A., Jagoutz, E., and Grousset, F.: Comparing the Epica and Vostok dust records during the last 220,000 years: stratigraphical correlation and provenance in glacial periods, Earth-Sci. Rev., 66, 63-87, 2004.

Efron, B.: Better Bootstrap Confidence Intervals, Journal of the American Statistical Association, 82, 171-185, 1987.

Fischer, H., Siggaard-Andersen, M.-L., Ruth, U., Rothlisberger, R., and Wolff, E.: Glacial/interglacial changes in mineral dust and sea-salt records in polar ice cores: Sources, transport, and deposition, Rev. Geophys., 45, RG1002, doi:10.1029/2005rg000192, 2007.

Frezzotti, M., Bitelli, G., de Michelis, P., Deponti, A., Forieri, A., Gandolfi, S., Maggi, V., Mancini, F., Remy, F., rique, Tabacco, I. E., Urbini, S., Vittuari, L., and Zirizzottl, A.: Geophysical survey at Talos Dome, East Antarctica: the search for a new deep-drilling site, Ann. Glaciol., 39, 423-432, doi:10.3189/172756404781814591, 2004.

Frieß, U., Hollwedel, J., König-Langlo, G., Wagner, T., and Platt, U.: Dynamics and chemistry of tropospheric bromine explosion events in the Antarctic coastal region, J. Geophys. Res., 109, D06305, doi:10.1029/2003jd004133, 2004.

Frieß, U., Deutschmann, T., Gilfedder, B. S., Weller, R., and Platt, U.: Iodine monoxide in the Antarctic snowpack, Atmos. Chem. Phys., 10, 2439-2456, doi:10.5194/acp-10-2439-2010, 2010.

Gersonde, R., Crosta, X., Abelmann, A., and Armand, L.: Seasurface temperature and sea ice distribution of the Southern Ocean at the EPILOG Last Glacial Maximum-a circumAntarctic view based on siliceous microfossil records, Quaternary Sci. Rev., 24, 869-896, 2005.

Gilfedder, B. S., Lai, S. C., Petri, M., Biester, H., and Hoffmann, T.: Iodine speciation in rain, snow and aerosols, Atmos. Chem. Phys., 8, 6069-6084, doi:10.5194/acp-8-6069-2008, 2008.
Greenwood, N. N. and Earnshaw, A.: Chemestry of the elments, Elsevier, Amsterdam, The Netherlands, 1342, 2005.

Jones, A. E., Wolff, E. W., Salmon, R. A., Bauguitte, S. J.-B., Roscoe, H. K., Anderson, P. S., Ames, D., Clemitshaw, K. C., Fleming, Z. L., Bloss, W. J., Heard, D. E., Lee, J. D., Read, K. A., Hamer, P., Shallcross, D. E., Jackson, A. V., Walker, S. L., Lewis, A. C., Mills, G. P., Plane, J. M. C., Saiz-Lopez, A., Sturges, W. T., and Worton, D. R.: Chemistry of the Antarctic Boundary Layer and the Interface with Snow: an overview of the CHABLIS campaign, Atmos. Chem. Phys., 8, 3789-3803, doi:10.5194/acp-8-3789-2008, 2008.

Kaleschke, L., Richter, A., Burrows, J., Afe, O., Heygster, G., Notholt, J., Rankin, A., Roscoe, H., Hollwedel, J., and Wagner, T.: Frost flowers on sea ice as a source of sea salt and their influence on tropospheric halogen chemistry, Geophys. Res. Lett., 31, L16114, doi:10.1029/2004GL020655, 2004.

Kaufmann, P. R., Federer, U., Hutterli, M. A., Bigler, M., Schupbach, S., Ruth, U., Schmitt, J., and Stocker, T. F.: An Improved Continuous Flow Analysis System for High-Resolution Field Measurements on Ice Cores, Environ. Sci. Tech., 42, 8044-8050, doi:10.1021/es8007722, 2008.

Lambert, F., Delmonte, B., Petit, J. R., Bigler, M., Kaufmann, P. R., Hutterli, M. A., Stocker, T. F., Ruth, U., Steffensen, J. P., and Maggi, V.: Dust-climate couplings over the past 800,000 years from the EPICA Dome C ice core, Nature, 452, 616-619, 2008.

Lisiecki, L. E. and Raymo, M. E.: A Pliocene-Pleistocene stack of 57 globally distributed benthic $\delta^{18} \mathrm{O}$ records, Paleoceanography, 20, PA1003, doi:10.1029/2004pa001071, 2005.

Ma, J. and Daggupaty, S. M.: Effective Dry Deposition Velocities for Gases and Particles over Heterogeneous Terrain, J. Appl. Meteorol., 39, 1379-1390, doi:10.1175/15200450(2000)039<1379:eddvfg>2.0.co;2, 2000.

Mahajan, A. S., Plane, J. M. C., Oetjen, H., Mendes, L., Saunders, R. W., Saiz-Lopez, A., Jones, C. E., Carpenter, L. J., and McFiggans, G. B.: Measurement and modelling of tropospheric reactive halogen species over the tropical Atlantic Ocean, Atmos. Chem. Phys., 10, 4611-4624, doi:10.5194/acp-10-4611-2010, 2010

Martin, J. H.: Glacial-Interglacial $\mathrm{CO}_{2}$ Change: The Iron Hypothesis, Paleoceanography, 5, 1-13, doi:10.1029/PA005i001p00001, 1990.

McFiggans, G., Coe, H., Burgess, R., Allan, J., Cubison, M., Alfarra, M. R., Saunders, R., Saiz-Lopez, A., Plane, J. M. C., Wevill, D., Carpenter, L., Rickard, A. R., and Monks, P. S.: Direct evidence for coastal iodine particles from Laminaria macroalgae - linkage to emissions of molecular iodine, Atmos. Chem. Phys., 4, 701-713, doi:10.5194/acp-4-701-2004, 2004.

Millero, F. J.: The Physical Chemistry of Seawater, Annu. Rev. Earth Planet. Sci., 2, 101, 1974.

Nghiem, S. V., Rigor, I. G., Richter, A., Burrows, J. P., Shepson, P. B., Bottenheim, J., Barber, D. G., Steffen, A., Latonas, J., Wang, F., Stern, G., Clemente-Colòn, P., Martin, S., Hall, D. K., Kaleschke, L., Tackett, P., Neumann, G., and Asplin, M. G.: Field and satellite observations of the formation and distribution of Arctic atmospheric bromine above a rejuvenated sea ice cover, J. Geophys. Res., 117, D00S05, doi:10.1029/2011JD016268, 2012.

Oldridge, N. W. and Abbatt, J. P. D.: Formation of Gas-Phase Bromine from Interaction of Ozone with Frozen and Liquid $\mathrm{NaCl} / \mathrm{NaBr}$ Solutions: Quantitative Separation of Surficial Chemistry from Bulk-Phase Reaction, J. Phys. Chem. A, 115, 
2590-2598, doi:10.1021/jp200074u, 2011.

Oltmans, S. J.: Surface Ozone Measurements in Clean Air, J. Geophys. Res., 86, 1174-1180, doi:10.1029/JC086iC02p01174, 1981.

Pechtl, S., Lovejoy, E. R., Burkholder, J. B., and von Glasow, R.: Modeling the possible role of iodine oxides in atmospheric new particle formation, Atmos. Chem. Phys., 6, 505-523, doi:10.5194/acp-6-505-2006, 2006.

Petit, J. R. and Delmonte, B.: A model for large glacial-interglacial climate-induced changes in dust and sea salt concentrations in deep ice cores (central Antarctica): palaeoclimatic implications and prospects for refining ice core chronologies, Tellus B, 61, 768-790, 2009.

Petit, J. R., Jouzel, J., Raynaud, D., Barkov, N. I., Barnola, J. M., Basile, I., Bender, M., Chappellaz, J., Davis, M., Delaygue, G., Delmotte, M., Kotlyakov, V. M., Legrand, M., Lipenkov, V. Y., Lorius, C., Pepin, L., Ritz, C., Saltzman, E., and Stievenard, M.: Climate and atmospheric history of the past 420,000 years from the Vostok ice core, Antarctica, Nature, 399, 429-436, 1999.

Pratt, K. A., Custard, K. D., Shepson, P. B., Douglas, T. A., Pohler, D., General, S., Zielcke, J., Simpson, W. R., Platt, U., Tanner, D. J., Gregory Huey, L., Carlsen, M., and Stirm, B. H.: Photochemical production of molecular bromine in Arctic surface snowpacks, Nature Geosci, 6, 351-356, doi:10.1038/ngeo1779, 2013.

Rankin, A. M., Auld, V., and Wolff, E. W.: Frost flowers as a source of fractionated sea salt aerosol in the polar regions, Geophys. Res. Lett., 27, 3469-3472, 2000.

Read, K. A., Lewis, A. C., Salmon, R. A., Jones, A. E., and Bauguitte, S.: $\mathrm{OH}$ and halogen atom influence on the variability of nonmethane hydrocarbons in the Antarctic Boundary Layer, Tellus B, 59, 22-38, doi:10.1111/j.1600-0889.2006.00227.x, 2007.

Saiz-Lopez, A. and Boxe, C. S.: A mechanism for biologicallyinduced iodine emissions from sea-ice, Atmos. Chem. Phys. Discuss., 8, 2953-2976, doi:10.5194/acpd-8-2953-2008, 2008.

Saiz-Lopez, A. and Plane, J.: Novel iodine chemistry in the marine boundary layer, Geophys. Res. Lett., 31, L04112, doi:10.1029/2003GL019215, 2004.

Saiz-Lopez, A., Saunders, R. W., Joseph, D. M., Ashworth, S. H., and Plane, J. M. C.: Absolute absorption cross-section and photolysis rate of $\mathrm{I}_{2}$, Atmos. Chem. Phys., 4, 1443-1450, doi:10.5194/acp-4-1443-2004, 2004.

Saiz-Lopez, A., Chance, K., Liu, X., Kurosu, T. P., and Sander, S. P.: First observations of iodine oxide from space, Geophys. Res. Lett., 34, L12812, doi:10.1029/2007GL030111, 2007 a.

Saiz-Lopez, A., Mahajan, A. S., Salmon, R. A., Bauguitte, S. J. B., Jones, A. E., Roscoe, H. K., and Plane, J. M. C.: Boundary Layer Halogens in Coastal Antarctica, Science, 317, 348-351, $2007 \mathrm{~b}$.

Saiz-Lopez, A., Plane, J. M. C., Mahajan, A. S., Anderson, P. S., Bauguitte, S. J.-B., Jones, A. E., Roscoe, H. K., Salmon, R. A., Bloss, W. J., Lee, J. D., and Heard, D. E.: On the vertical distribution of boundary layer halogens over coastal Antarctica: implications for $\mathrm{O}_{3}, \mathrm{HO}_{\mathrm{x}}, \mathrm{NO}_{\mathrm{x}}$ and the $\mathrm{Hg}$ lifetime, Atmos. Chem. Phys., 8, 887-900, doi:10.5194/acp-8-887-2008, 2008.

Saiz-Lopez, A., Plane, J. M. C., Baker, A. R., Carpenter, L. J., von Glasow, R., Gómez Martin, J. C., McFiggans, G., and Saunders, R. W.: Atmospheric chemistry of iodine, Chem. Rev., 112, 17731804, 2012
Saunders, R. W. and Plane, J. M. C.: Formation Pathways and Composition of Iodine Oxide Ultra-Fine Particles, Environ. Chem., 2, 299-303, 2005.

Saunders, R. W., Kumar, R., Gomez Martin, J. C., Mahajan, A. S., Murray, B. J., and Plane, J. M. C.: Studies of the Formation and Growth of Aerosol from Molecular Iodine Precursor, Zeitschrift für Physikalische Chemie, 224, 1095-1117, doi:10.1524/zpch.2010.6143, 2010.

Saunders, R. W., Dhomse, S., Tian, W. S., Chipperfield, M. P., and Plane, J. M. C.: Interactions of meteoric smoke particles with sulphuric acid in the Earth's stratosphere, Atmos. Chem. Phys., 12, 4387-4398, doi:10.5194/acp-12-4387-2012, 2012a.

Saunders, R. W., Kumar, R., MacDonald, S. M., and Plane, J. M. C.: Insights into the Photochemical Transformation of Iodine in Aqueous Systems: Humic Acid Photosensitized Reduction of Iodate, Environ. Sci. Technol., 46, 11854-11861, doi:10.1021/es3030935, 2012b.

Sazaki, G., Zepeda, S., Nakatsubo, S., Yokomine, M., and Furukawa, Y.: Quasi-liquid layers on ice crystal surfaces are made up of two different phases, P. Natl. Acad. Sci., 4, 1052-1055, doi:10.1073/pnas.1116685109, 2012.

Scarchilli, C., Frezzotti, M., and Ruti, P.: Snow precipitation at four ice core sites in East Antarctica: provenance, seasonality and blocking factors, Clim. Dyn., 37, 2107-2125, doi:10.1007/s00382-010-0946-4, 2011.

Schönhardt, A., Richter, A., Wittrock, F., Kirk, H., Oetjen, H., Roscoe, H. K., and Burrows, J. P.: Observations of iodine monoxide columns from satellite, Atmos. Chem. Phys., 8, 637-653, doi:10.5194/acp-8-637-2008, 2008.

Schönhardt, A., Begoin, M., Richter, A., Wittrock, F., Kaleschke, L., Gómez Martín, J. C., and Burrows, J. P.: Simultaneous satellite observations of IO and BrO over Antarctica, Atmos. Chem. Phys., 12, 6565-6580, doi:10.5194/acp-12-6565-2012, 2012.

Schüpbach, S., Federer, U., Bigler, M., Fischer, H., and Stocker, T. F.: A refined TALDICE-1a age scale from 55 to $112 \mathrm{ka}$ before present for the Talos Dome ice core based on highresolution methane measurements, Clim. Past, 7, 1001-1009, doi:10.5194/cp-7-1001-2011, 2011.

Simpson, W. R., Alvarez-Aviles, L., Douglas, T. A., Sturm, M., and Domine, F.: Halogens in the coastal snow pack near Barrow, Alaska: Evidence for active bromine air-snow chemistry during springtime, Geophys. Res. Lett., 32, L04811, doi:10.1029/2004g1021748, 2005.

Simpson, W. R., Carlson, D., Hönninger, G., Douglas, T. A., Sturm, M., Perovich, D., and Platt, U.: First-year sea-ice contact predicts bromine monoxide $(\mathrm{BrO})$ levels at Barrow, Alaska better than potential frost flower contact, Atmos. Chem. Phys., 7, 621-627, doi:10.5194/acp-7-621-2007, 2007a.

Simpson, W. R., von Glasow, R., Riedel, K., Anderson, P., Ariya, P., Bottenheim, J., Burrows, J., Carpenter, L. J., Frieß, U., Goodsite, M. E., Heard, D., Hutterli, M., Jacobi, H.-W., Kaleschke, L., Neff, B., Plane, J., Platt, U., Richter, A., Roscoe, H., Sander, R., Shepson, P., Sodeau, J., Steffen, A., Wagner, T., and Wolff, E.: Halogens and their role in polar boundary-layer ozone depletion, Atmos. Chem. Phys., 7, 4375-4418, doi:10.5194/acp-74375-2007, 2007b.

Smith, B. T., Van Ommen, T. D., and Curran, M. A. J.: Methanesulphonic acid movement in solid ice cores, Ann. Glaciol., 39, 540-544, 2004. 
Spolaor, A., Vallelonga, P., Gabrieli, J., Kehrwald, N., Turetta, C., Cozzi, G., Poto, L., Plane, J. C., Boutron, C., and Barbante, C.: Speciation analysis of iodine and bromine at picogramper-gram levels in polar ice, Anal. Bioanal. Chem., 405, 1-8, doi:10.1007/s00216-012-5806-0, 2012.

Stenni, B., Buiron, D., Frezzotti, M., Albani, S., Barbante, C., Bard, E., Barnola, J. M., Baroni, M., Baumgartner, M., Bonazza, M., Capron, E., Castellano, E., Chappellaz, J., Delmonte, B., Falourd, S., Genoni, L., Iacumin, P., Jouzel, J., Kipfstuhl, S., Landais, A., Lemieux-Dudon, B., Maggi, V., Masson-Delmotte, V., Mazzola, C., Minster, B., Montagnat, M., Mulvaney, R., Narcisi, B., Oerter, H., Parrenin, F., Petit, J. R., Ritz, C., Scarchilli, C., Schilt, A., Schupbach, S., Schwander, J., Selmo, E., Severi, M., Stocker, T. F., and Udisti, R.: Expression of the bipolar see-saw in Antarctic climate records during the last deglaciation, Nature Geosci., 4, 46-49, 2011.

Vogt, R.: Iodine compounds in the atmosphere, edited by: Fabian, P. and Singh, O. N., Reactive Halogen Compounds in the Atmosphere, Springer-Verlag, Berlin, 113-128, 1999.

Vogt, R., Crutzen, P. J., and Sander, R.: A mechanism for halogen release from sea-salt aerosol in the remote marine boundary layer, Nature, 383, 327-330, 1996.

Vogt, R., Sander, R., Von Glasow, R., and Crutzen, P.: Iodine chemistry and its role in halogen activation and ozone loss in the marine boundary layer: A model study, J. Atmos. Chem., 32, 375395, 1999.
Wagenbach, D., Ducroz, F., Mulvaney, R., Keck, L., Minikin, A., Legrand, M., Hall, J. S., and Wolff, E. W.: Sea-salt aerosol in coastal Antarctic regions, J. Geophys. Res.-Atmos., 103, 1096110974, doi:10.1029/97jd01804, 1998.

Wofsy, S. C., McElroy, M. B., and Yung, Y. L.: The chemistry of atmospheric bromine, Geophys. Res. Lett., 2, 215-218, doi:10.1029/GL002i006p00215, 1975.

Wolff, E., Fischer, H., Fundel, F., Ruth, U., Twarloh, B., Littot, G. C., Mulvaney, R., Rothlisberger, R., de Angelis, M., Boutron, C. F., Hansson, M., Jonsell, U., Hutterli, M. A., Lambert, F., Kaufmann, P., Stauffer, B., Stocker, T. F., Steffensen, J. P., Bigler, M., Siggaard-Andersen, M. L., Udisti, R., Becagli, S., Castellano, E., Severi, M., Wagenbach, D., Barbante, C., Gabrielli, P., and Gaspari, V.: Southern Ocean sea-ice extent, productivity and iron flux over the past eight glacial cycles, Nature, 440, 491-496, 2006.

Wolff, E., Barbante, C., Becagli, S., Bigler, M., Boutron, C., Castellano, E., De Angelis, M., Federer, U., Fischer, H., and Fundel, F.: Changes in environment over the last 800,000 years from chemical analysis of the EPICA Dome C ice core, Quaternary Sci. Rev., 29, 285-295, 2010.

Wong, G. T. F.: The Marine Geochemistry of Iodine, Rev. Aquat. Sci., 4, 45-73, 1991. 